\title{
Contraception: answers of wives and husbands compared in a survey of Swiss couples
}

\author{
Höpflinger, F ; Kühne, F
}

\begin{abstract}
In a survey of Swiss couples, the husband-wife agreement on contraception (current use, and methods ever used) is high and husbands are generally as well informed on the use of contraceptive methods as their wives. The data indicate that the use of condoms may be underestimated in interviewing women only and that the contraceptive behaviour of a couple is related to the fertility preferences of both wife and husband
\end{abstract}

DOI: https://doi.org/10.1017/s0021932000015030

Posted at the Zurich Open Repository and Archive, University of Zurich

ZORA URL: https://doi.org/10.5167/uzh-154017

Journal Article

Published Version

Originally published at:

Höpflinger, F; Kühne, F (1984). Contraception: answers of wives and husbands compared in a survey of Swiss couples. Journal of Biosocial Science, 16(2):259-268.

DOI: https://doi.org/10.1017/s0021932000015030 


\title{
CONTRACEPTION: ANSWERS OF WIVES AND HUSBANDS COMPARED IN A SURVEY OF SWISS COUPLES
}

\author{
F. HÖPFLINGER* AND F. KÜHNE† \\ * Centre for Population Studies, London School of Hygiene and Tropical \\ Medicine, and †Institute of Sociology, University of Zurich
}

\begin{abstract}
Summary. In a survey of Swiss couples, the husband-wife agreement on contraception (current use, and methods ever used) is high and husbands are generally as well informed on the use of contraceptive methods as their wives. The data indicate that the use of condoms may be underestimated in interviewing women only and that the contraceptive behaviour of a couple is related to the fertility preferences of both wife and husband.
\end{abstract}

\section{Introduction}

Most of the studies on decisions regarding fertility or family planning focus on women, despite the fact that such decisions in modern societies tend to be made by couples rather than by women alone (Beckman, 1978). For practical reasons women are preferable as respondents. Most fertility statistics are female-specific, and there have been few attempts to compute male fertility rates (Brouard, 1977). Women obviously report pregnancies and birth histories more accurately, because of their involvement throughout and at the end of a pregnancy, while the presence of men is not essential. In most families the wife is more involved in family affairs (housekeeping, education of children) than her husband, and for that reason fertility decisions are strongly influenced by her views, even within egalitarian societies. Finally the woman's reproductive career, unlike that of a man, is patterned in time and dependent on the cycle of menstruation, which allows for more precision in time-specific measurement (Ryder, 1975).

These practicalities may lead to systematic biases in interpretation. 'One of the glaring shortcomings of many family planning studies has been their frequent absence of concern for the role of the husband in the family planning process' (Jaco \& Shepard, 1975).

The few studies which included both partners in examining fertility decisions revealed considerable wife-husband differences in measured fertility preferences (Bisson \& Piché, 1977; Cochrane \& Bean, 1976; Coombs \& Fernandez, 1978; Höpflinger \& Kühne, 1979). A two-sex model can be a better predictor of reproductive intentions than a one-sex model (Fried, Hofferth \& Udry, 1980; Udry, 
1982; Höpflinger, 1982), and a review of Latin American studies revealed the importance of the husband's opinion in the decision on use of contraception, especially in areas where contraception is not a common practice and is perceived as deviant behaviour (Hollerbach, 1980). One study (Card, 1978) showed that consideration of the husband's view accounted for the observed discrepancies in the wife's motivation for fertility control and their contraceptive behaviour.

In the present article, data from a survey in Switzerland which incorporated both partners' views are analysed to determine the level of agreement between wives and husbands in relation to contraception: current use, ever used, and knowledge of methods. Another object was to evaluate the role of men in influencing contraceptive behaviour.

\section{Data}

As part of a research project on fertility decline in Switzerland, 600 Swiss couples married between 1970 and 1979 were interviewed to determine their fertility preferences and contraceptive behaviour. The survey was conducted during autumn 1980 and included couples in their first marriages from both the German-speaking and the French-speaking parts of Switzerland. A two-stage sampling procedure (selection of communities proportional to the total population distribution followed by random sampling of couples within the communities) was used.

With the exception of pregnancy history, the wife and the husband were asked the same questions. In $90 \%$ of the interviews husband and wife were interviewed at the same time but separately, in different rooms, with no opportunity for discussion. The wife was interviewed by a female, the man by a male interviewer.

In the following analysis the responses of wives and husbands regarding contraceptive knowledge, behaviour and evaluation are compared, in terms of both aggregate distributions and paired relations. By viewing the respondents as couples the proportion of identical responses and the degree of discordance can be measured.

\section{Analysis}

\section{Knowledge of contraceptive methods}

The respondents were asked to name all the contraceptive methods they knew about. A full list of possible contraceptive methods (including the different popular expressions of methods) was then presented, and the respondents were asked to indicate all the methods that they had ever heard of. Knowledge in this sense is a rather poor concept, as the naming of a specific method ranges from simply having heard about it to a practical understanding of its application.

Of the various contraceptive methods, virtually all Swiss couples spontaneously mentioned the pill. A large majority of respondents also knew about the IUD and the condom. Douching and the diaphragm on the other hand were rather unfamiliar methods, as was particularly apparent in the spontaneous naming of methods. Sterilization, withdrawal and temperature were quite well-known, in the sense of 'ever heard of' but were not among the spontaneously named methods. 
Table 1. Knowledge of contraceptive methods: answers of wives and husbands (601 couples)

\begin{tabular}{|c|c|c|c|c|}
\hline \multirow[b]{2}{*}{ Contraceptive method } & \multicolumn{2}{|c|}{$\begin{array}{l}\text { Spontaneously } \\
\text { remembered }\end{array}$} & \multicolumn{2}{|c|}{ Ever heard of $\dagger$} \\
\hline & $\begin{array}{l}\text { Wives } \\
(\%)\end{array}$ & $\begin{array}{l}\text { Husbands } \\
\text { (\%) }\end{array}$ & $\begin{array}{l}\text { Wives } \\
\text { (\%) }\end{array}$ & $\begin{array}{l}\text { Husbands } \\
\text { (\%) }\end{array}$ \\
\hline Pill & $96 \cdot 2$ & 91.7 & $99 \cdot 2$ & 97.5 \\
\hline IUD & $76 \cdot 4^{*}$ & $66 \cdot 9$ & $95 \cdot 5$ & $92 \cdot 3$ \\
\hline Condom & $66 \cdot 2^{*}$ & 84.4 & 94.0 & 97.0 \\
\hline Sterilization & $43 \cdot 3$ & 47.6 & $92 \cdot 7$ & $90 \cdot 7$ \\
\hline Cream, jelly & $36 \cdot 3$ & 31.9 & $76 \cdot 2$ & $72 \cdot 5$ \\
\hline Suppositories & $33 \cdot 8^{*}$ & $25 \cdot 6$ & $76 \cdot 2^{*}$ & $65 \cdot 9$ \\
\hline Temperature & $26 \cdot 8$ & $25 \cdot 1$ & $90 \cdot 7^{*}$ & 77.5 \\
\hline Calendar (Ogino-Knaus) & $26 \cdot 3$ & 30.8 & $79 \cdot 0$ & 78.6 \\
\hline Withdrawal & $21 \cdot 8^{*}$ & $33 \cdot 8$ & $82 \cdot 0$ & 89.5 \\
\hline Diaphragm & $18 \cdot 0$ & $17 \cdot 1$ & $56 \cdot 6$ & 53.4 \\
\hline Douching & 7.8 & $7 \cdot 7$ & $49 \cdot 1$ & $46 \cdot 3$ \\
\hline
\end{tabular}

$\dagger$ After presentation of a list.

* Differences between wives and husbands significant at $1 \%\left(x^{2}\right.$ test for two independent samples.

This might have been a result of embarrassment or because some people do not consider sterilization and withdrawal as forms of contraception.

Husbands named condoms - a male method-and withdrawal more often than their wives (Table 1), but the significances of the differences disappear in the proportion of wives and husbands who have heard of the two methods in the prompted list.

On the other hand, the wives seemed better informed about both temperature and suppositories, two typical female methods. Apart from these two methods, the husbands were generally as well informed as their wives. Educational achievement and social status were the most important factors associated with the number of methods ever heard of for both wives and husbands.

\section{Contraceptive behaviour: methods in current use and ever-used}

Regarding contraceptives which had ever been used and those in current use, the same list of the known methods of contraception (and their popular expressions) was introduced to both husbands and wives to ensure the same frame of reference.

In Switzerland, as is the case in other developed countries, the pill was found to be the most popular contraceptive method, followed by sterilization, IUDs and condoms. Also as in other European countries (Leridon, 1980; Lightbourne \& Singh, 1982), the most popular methods in Switzerland were the most effective. 
Table 2. Current contraceptive practice: answers of wives and husbands (601 couples)

\begin{tabular}{lrr}
\hline \multicolumn{1}{c}{ Current use } & $\begin{array}{c}\text { Wives } \\
\text { (\%) }\end{array}$ & $\begin{array}{c}\text { Husbands } \\
(\%)\end{array}$ \\
\hline No contraception & 29.6 & 26.6 \\
Pill & 26.3 & 26.6 \\
Sterilization (vasectomy, tubectomy) & 14.6 & 14.3 \\
IUD & 10.5 & 9.8 \\
Condom & 7.5 & 8.8 \\
Calendar (Ogino-Knaus) & 2.8 & 3.0 \\
Withdrawal & 1.7 & 1.8 \\
Temperature & 1.5 & 1.0 \\
Other method & 2.7 & 2.5 \\
No answers & 2.8 & 5.5 \\
\hline
\end{tabular}

Similarly the levels of contraceptive use by married couples were as high as in other developed countries, and few Swiss couples (about 5\%) were fundamentally non-users.

The statements of wives and husbands did not reveal any great discrepancies (Table 2). This indicates that men can be regarded as reliable informants on current contraceptive use, at least in a country such as Switzerland where family planning is well established. Only a marginally higher percentage of non-respondents was observed among men as compared to women. A tendency for women to state more frequently that they did not use contraceptives was observed but was not statistically significant. In addition, women tended to report less condom use. This too was not statistically significant but still hints at a possible under-reporting of male dependent contraceptive measures. This study suggests that women tend to be more reluctant to mention such methods.

Another aspect of agreement is revealed by viewing wives and husbands as a pair. Less concordance is expected, as aggregate similarities tend to mask variations in differing directions.

The husband-wife agreement on current contraceptive practice is quite high but is not perfect: only $78 \%$ of the couples gave concordant statements. This indicates problems of validity in the measurement of a relatively unambiguous concept (Table 3). Yet consensus of spouses on current contraceptive use is higher than in other family data, especially soft data such as family attitudes or the perception of power (Ballweg, 1969; Both \& Welch, 1978; Höpflinger \& Kühne, 1979).

Detailed analysis of the discordant answers shows that for $7 \%$ of the couples there is discordance about the specific method used. In $15.5 \%$ of the couples one of the two partners denies the use of any contraception. But there is no sex-specific bias and husbands do not tend to deny the use of contraception more often than their wives.

The paired comparison reveals a second tendency: the statement of the wife is more often confirmed by her husband when a modern contraceptive method (pill, 
Table 3. Current contraceptive practice: husband-wife agreement (556 couples)

\begin{tabular}{|c|c|c|c|c|c|c|c|c|}
\hline \multirow[b]{2}{*}{$\begin{array}{l}\text { Method stated } \\
\text { by wife }\end{array}$} & \multicolumn{6}{|c|}{ Method stated by husband } & \multirow{2}{*}{$\begin{array}{l}\text { Husbands' } \\
\text { confirmation } \\
\text { of wives' } \\
\text { statements } \\
\text { (\%) }\end{array}$} & \multirow[b]{2}{*}{$N$} \\
\hline & $\begin{array}{l}\text { Pill } \\
(\%)\end{array}$ & $\begin{array}{l}\text { Sterilization } \\
\text { (\%) }\end{array}$ & $\begin{array}{l}\text { Condom } \\
(\%)\end{array}$ & $\begin{array}{c}\text { IUD } \\
(\%)\end{array}$ & $\begin{array}{c}\text { Other } \\
\text { (\%) }\end{array}$ & $\begin{array}{c}\text { None } \\
\text { used } \\
(\%)\end{array}$ & & \\
\hline Pill & $24 \cdot 5$ & 0.2 & 0.7 & 0.0 & 0.6 & 1.4 & 89.5 & 152 \\
\hline Sterilization & 0.5 & 12.6 & 0.0 & 0.0 & 0.0 & 1.7 & 85.4 & 82 \\
\hline Condom & 0.9 & 0.2 & $5 \cdot 4$ & 0.0 & 0.8 & 0.8 & $68 \cdot 2$ & 44 \\
\hline IUD & 0.5 & 0.0 & 0.0 & 9.9 & 0.4 & 0.0 & 91.7 & 60 \\
\hline Other & 0.6 & 0.0 & 1.6 & 0.0 & 4.5 & 2.9 & 46.9 & 52 \\
\hline None used & 1.8 & 2.5 & 1.4 & 0.4 & 2.6 & 21.0 & $70 \cdot 5$ & 166 \\
\hline \multicolumn{9}{|c|}{$\begin{array}{l}\text { Concordant statements: } 77.9 \% \text { of couples } \\
\text { Discordant statements: } 22 \cdot 1 \% \text { of couples }\end{array}$} \\
\hline
\end{tabular}

IUD, sterilization) is used. The agreement is lower for couples who practise traditional or marginal methods. The measurement errors vary with methods: there are small errors for modern, well known contraceptives and large errors for traditional or marginal methods. It may be that couples who use traditional methods are more ambivalent about fertility control or more embarrassed to answer questions on it.

In the aggregate comparison for methods ever used (Table 4), it must be kept in mind that methods recently used are more likely to be reported than those used long

Table 4. Contraceptive methods ever used: answers of wives and husbands ( 601 couples)

\begin{tabular}{|c|c|c|}
\hline Method & $\begin{array}{l}\text { Wives } \\
(\%)\end{array}$ & $\begin{array}{l}\text { Husbands } \\
\text { (\%) }\end{array}$ \\
\hline Pill & $82 \cdot 0$ & $77 \cdot 7$ \\
\hline Condom & $41 \cdot 9^{*}$ & $51 \cdot 9$ \\
\hline Withdrawal & $23 \cdot 0$ & 25.0 \\
\hline IUD & $19 \cdot 5$ & 17.6 \\
\hline Sterilization (vasectomy, tubectomy) & $15 \cdot 3$ & $15 \cdot 5$ \\
\hline Calendar (Ogino-Knaus) & $14 \cdot 1$ & $13 \cdot 5$ \\
\hline Suppositories & $14 \cdot 1$ & $10 \cdot 5$ \\
\hline Temperature & $12 \cdot 0$ & $7 \cdot 5$ \\
\hline Cream, jelly & $6 \cdot 3$ & $6 \cdot 2$ \\
\hline Diaphragm & 1.3 & $1 \cdot 2$ \\
\hline Douching & 0.7 & 0.7 \\
\hline
\end{tabular}

* Difference between wives and husbands significant at $1 \%$ ( $\chi^{2}$ test for two independent samples). 
ago. For methods ever used there are problems of recall and memory lapses. When couples are interviewed, a further problem arises: wives and husbands may have different time references even when a question refers explicitly to contraception after marriage.

Nevertheless in the comparison of the aggregate statements of husbands and wives, the rank-order of methods ever used is the same for wives and husbands and the differences are relatively small, with one exception: husbands tend to mention condoms significantly more often than their wives. This result suggests that the use of condoms may be systematically underestimated by interviewing women only. Ambiguities in relation to time reference or questions that refer to the contraceptive behaviour of the women, and not of the couple, may increase such a bias in many family planning studies.

The comparison of pairs also indicates that condoms are less often named by women than men (Table 5), while withdrawal and calendar-two traditional methods - also lead to a high level of disagreement, probably associated with the fact that these methods are primarily used at the beginning of marriage or in combination with other, e.g. chemical, methods.

If the degree of agreement between husband and wife is taken as an indicator of the validity of the measurement, it could be concluded that the coitus-independent methods (pill, IUD) are relatively well remembered, in contrast to the coitusdependent methods (e.g. condoms, withdrawal, suppositories). It may be that the interference of these methods with sexual intercourse and the fact that coitusdependent methods are often the earlier methods used by a couple increase errors of recall.

Table 5. Contraceptive methods ever used: husband-wife agreement (601 couples)

\begin{tabular}{|c|c|c|c|c|c|}
\hline \multirow[b]{2}{*}{ Method } & \multicolumn{4}{|c|}{ Statements of husband and wife } & \multirow[b]{2}{*}{$\begin{array}{c}\% \\
\text { disagreement }\end{array}$} \\
\hline & $\begin{array}{l}\text { Both: } \\
\text { never } \\
\text { used } \\
(\%)\end{array}$ & $\begin{array}{l}\text { Both: } \\
\text { used } \\
\text { (\%) }\end{array}$ & $\begin{array}{l}\text { Husband: } \\
\text { used, wife: } \\
\text { never used } \\
\quad(\%)\end{array}$ & $\begin{array}{l}\text { Husband: } \\
\text { never used, } \\
\text { wife: used } \\
(\%)\end{array}$ & \\
\hline Pill & $14 \cdot 5$ & $74 \cdot 2$ & $3 \cdot 5$ & $7 \cdot 8$ & $11 \cdot 3$ \\
\hline Condom & $38 \cdot 3$ & $32 \cdot 1$ & $19 \cdot 8$ & 9.8 & $29 \cdot 6$ \\
\hline Withdrawal & 61.6 & $9 \cdot 5$ & $15 \cdot 4$ & 13.5 & $28 \cdot 9$ \\
\hline IUD & 79.0 & $15 \cdot 9$ & 1.7 & 3.5 & $5 \cdot 2$ \\
\hline Sterilization & 81.9 & $12 \cdot 6$ & $2 \cdot 8$ & $2 \cdot 6$ & $5 \cdot 5$ \\
\hline Calendar (Ogino-Knaus) & $76 \cdot 7$ & $4 \cdot 3$ & $10 \cdot 0$ & 9.2 & $19 \cdot 2$ \\
\hline Suppositories & $80 \cdot 7$ & $5 \cdot 3$ & $5 \cdot 2$ & $8 \cdot 8$ & $14 \cdot 0$ \\
\hline Temperature & 84.4 & 3.8 & $3 \cdot 6$ & $8 \cdot 1$ & 11.7 \\
\hline Cream & 89.7 & $2 \cdot 2$ & 4.0 & $4 \cdot 1$ & $8 \cdot 1$ \\
\hline Diaphragm & $98 \cdot 0$ & 0.5 & 0.6 & 0.8 & 1.4 \\
\hline Douching & $98 \cdot 8$ & $0 \cdot 1$ & 0.5 & 0.6 & $1 \cdot 1$ \\
\hline
\end{tabular}


The role of the husband in family planning

The process by which couples decide whether or not to use contraception, and which method, is still sketchy and incomplete (Beckman, 1978). This crosssectional study gives only crude information about the role of husbands in contraceptive decision-making. In an attempt to measure this, respondents who named a method as ever used were asked: 'Who first initiated the use of this specific method?'. Clearly, posing the question in this manner has several shortcomings and does not do justice to the complexity of real life. The answers reflect the subjective perception of family planning decisions (Table 6). The strong impact of the physician in the use of modern methods, such as the pill, IUD and sterilization, simply reflects the fact that these methods are available only through medical consultation. Consequently the wives place more emphasis on the role of the physician than do the husbands, who more often perceive family planning as a joint decision. The use of traditional methods, such as condoms and withdrawal, is perceived by a majority of users as the result of a joint decision, and secondly as a male-dominated and initiated decision - the latter particularly in the husbands' reports. This tendency may be interpreted either as an expression of the husband's interest in the decision or as a paternalistic attitude in a society where men are still the primary agents of family responsibility (Hollerbach, 1980).

Table 6. Perceived decision-making for different contraceptive methods ever used

\begin{tabular}{|c|c|c|c|c|c|c|}
\hline \multirow[b]{2}{*}{ Method } & \multicolumn{4}{|c|}{ Main initiator } & \multirow[b]{2}{*}{$\begin{array}{c}\text { No } \\
\text { answer } \\
(\%)\end{array}$} & \multirow[b]{2}{*}{$N \dagger$} \\
\hline & $\begin{array}{l}\text { Physician } \\
\text { (\%) }\end{array}$ & $\begin{array}{l}\text { Wife } \\
(\%)\end{array}$ & $\begin{array}{l}\text { Husband } \\
(\%)\end{array}$ & $\begin{array}{c}\text { Joint } \\
\text { decision } \\
(\%)\end{array}$ & & \\
\hline \multicolumn{7}{|l|}{ Wives' statements } \\
\hline Pill & 59 & 21 & 2 & 14 & 4 & 516 \\
\hline Condom & 10 & 10 & 21 & 53 & 6 & 261 \\
\hline Withdrawal & 4 & 17 & 17 & 55 & 7 & 139 \\
\hline IUD & 68 & 18 & 0 & 7 & 7 & 123 \\
\hline Sterilization & 39 & 10 & 7 & 27 & 17 & 90 \\
\hline Calendar (Ogino-Knaus) & 15 & 43 & 7 & 26 & 9 & 88 \\
\hline \multicolumn{7}{|l|}{ Husbands' statements } \\
\hline Pill* & 34 & 25 & 4 & 31 & 6 & 466 \\
\hline Condom* & 4 & 6 & 31 & 53 & 6 & 310 \\
\hline Withdrawal* & 1 & 6 & 25 & 62 & 6 & 148 \\
\hline IUD & 51 & 24 & 2 & 15 & 8 & 106 \\
\hline Sterilization & 32 & 14 & 6 & 39 & 9 & 94 \\
\hline Calendar (Ogino-Knaus) & 6 & 26 & 8 & 51 & 9 & 80 \\
\hline
\end{tabular}

† Respondents who named method as ever used.

* Differences between wives and husbands significant at $1 \%\left(\chi^{2}\right.$ test for two independent samples). 
It is true that the subjective perception of decision making may be only weakly related to the real process. To understand more clearly the influence of the husband, a multivariate analysis of the contraceptive behaviour of the couples was performed taking into account the social background or attitudes of both the husband and the wife (Table 7). The multivariate analysis showed that the use or non-use of contraceptives as well as the current use of a particular method were primarily related to demographic variables (number of children, marital duration, age of woman) and to the fertility preferences of wife and husband. Both the social status, as assessed by education and income, and the religion (Roman Catholic versus Protestant) of wife and husband had little effect. But religious attitudes, measured as valuing religion within the family, were significantly associated with contraceptive behaviour. Here an additive effect of the attitudes of wife and husband was observed: the pill and IUD are most frequently used when both partners gave no importance to religion. In instances where both spouses highly value religion, use of the condom was more often reported (17\%) as compared with an average of $6 \%$ in all other categories. Couples with heterogeneous religious attitudes showed an intermediate pattern. This relationship supports the idea that the husband's attitudes may reinforce or attenuate the motivation of the wife (Card, 1978). A direct effect of husband's religious attitudes, however, was only observed in the case of contraceptive sterilization, an effect which was significant even when parity, marital duration, age and religious attitude of wife were controlled.

The contraceptive behaviour of a couple is naturally also strongly associated with fertility preferences. There are no serious problems when wife and husband desire the same number of children and both decide either to have another child or

Table 7. Contraceptive sterilization: discriminant analysis in 480 couples with child(ren) between groups where wife reports sterilization* or no sterilization

\begin{tabular}{lc}
\hline \multicolumn{1}{c}{ Discriminating variable } & $\begin{array}{c}\text { Standardized discriminant } \\
\text { function coefficient }\end{array}$ \\
\hline No. of children & 0.62 \\
Valuing religion-husband & -0.39 \\
Previous stillbirth or premature birth & 0.32 \\
Age of wife & 0.31 \\
Duration of marriage & 0.19 \\
Education of wife & -0.15 \\
Education of husband & -0.12 \\
Valuing religion-wife & -0.07 \\
Discriminant function & \\
Canonical correlation & 0.482 \\
Wilks' $\lambda$ & 0.768 \\
Significance & $P<0.0001$ \\
\hline
\end{tabular}

* Vasectomy or tubectomy. 
Table 8. Current contraceptive use and fertility preference of wife and husband

\begin{tabular}{lccc}
\hline $\begin{array}{c}\text { Both partners } \\
\text { Current use } \\
\text { want a (another) } \\
\text { child } \\
(\%)\end{array}$ & $\begin{array}{c}\text { Neither partner } \\
\text { wants a (another) } \\
\text { child } \\
(\%)\end{array}$ & $\begin{array}{c}\text { One partner } \\
\text { wants a (another) } \\
\text { child } \\
(\%)\end{array}$ \\
\hline No contraception & 53.8 & 15.1 & 28.4 \\
Pill & 20.3 & 29.1 & 36.0 \\
Sterilization & 0.0 & 30.5 & 1.0 \\
IUD & 3.0 & 13.7 & 18.0 \\
Condom & 9.6 & 4.9 & 13.0 \\
Other method & 13.3 & 6.7 & 3.6 \\
$N$ & 197 & 285 & 102 \\
\hline
\end{tabular}

to limit their fertility. In the case of dissent between wife and husband and just one partner desires another child, an earlier study, based on longitudinal data, suggests that the partner who is not inclined to have another child exerts the greater weight (Jürgens \& Pohl, 1978). The results of our survey relate current contraceptive practice and the fertility preferences of both wife and husband (Table 8). The data demonstrate that contraceptive behaviour is, as expected, a couple's decision, influenced by the preferences of both partners. When both of the spouses wanted another child, now or later, $54 \%$ of the couples were non-users, in contrast to $15 \%$ for couples who agreed that their families were complete. More interesting is the case of discordant couples, for they show a pattern intermediate between these two.

The data reveal no difference in contraceptive practice when the wife only or when the husband only wants another child; $27 \%$ were non-users when it was only the wife who wanted a (another) child, and 30\% when it was the husband. There is no indication that the fertility preferences of the wife are more important, at least for the decision to use or not to use contraception.

The selection of a particular method seems to be related to the fertility preferences of both spouses. Voluntary sterilization is clearly confined to couples who agree that their family is complete. In cases of dissent, methods that are both efficient and reversible-pill, IUD or condom-are the most used. In such instances, which of the spouses wants to restrict fertility accounts for the decision on the method: the pill is more often used when the wife does not want a further child, the condom when it is the husband (perhaps related to the fact that in this way he has a direct control over contraception). But the number of such observations is small, and further data are required on this point.

\section{Conclusions}

This survey of Swiss couples shows that husbands are not less well informed on contraception and the current use of contraceptive methods than their wives. 
Husband-wife agreement about contraception (current use, methods ever used) is generally high but not perfect. First, the data indicate that the use of condoms-as a male method-may be systematically underestimated when only women are interviewed. Secondly, the paired comparison of answers about contraceptive behaviour indicated a degree of discordance more pronounced in the case of coitus-dependent than of coitus-independent methods.

The husbands perceive themselves as the active partner in family planning decisions more often than their wives do, but in fact the data demonstrate that the contraceptive behaviour of a couple is related to the fertility preferences of both wife and husband.

\section{References}

B ALLwEG, J.A. (1969) Husband-wife response similarities on evaluative and non-evaluative survey questions. Publ. Opinion Q. 2, 249.

BECKMAN, L.J. (1978) Couples' decision-making processes regarding fertility. In: Social Demography, pp 57-81. Edited by K.E. Taeuber, L.L. Bumpass and J.A. Sweet. Academic Press, London.

Bisson, A. \& PichÉ, V. (1977) L'accord conjugal en matière de fécondité et de planification familiale: une enquête au Quebec. Population, 1, 184.

Brouard, N. (1977) Evolution de la fécondité masculine depuis le début du siècle. Population, 6, 1123.

BоTH, A. \& W ELCH, S. (1978) Spousal consensus and its correlates: a reassessment. J. Marriage \& Fam. 40, 23.

CARD, J.J. (1978) The correspondence of data gathered from husband and wife: implications for family planning studies. Social Biol. 25, 196.

COCHRANE, S.H. \& BEAN, F.D. (1976) Husband-wife differences in the demand for children. $J$. Marriage \& Fam. 38, 297.

COOMBs, L.C. \& FERnandez, D. (1978) Husband-wife agreement about reproductive goals. Demography, 15, 57.

FrIEd, E.S., HofferTh, S.L. \& UDRY, J.R. (1980) Parity-specific and two-sex utility models of reproductive intentions. Demography, $17,1$.

Hollerbach, P.E. (1980) Power in families, communication and fertility decision-making. Popul. Envir. 3, 146.

HöPFLINGER, F. (1982) Geschlechtsspezifische Unterschiede im Kinderwunsch--Ergebnisse einer Befragung von Ehepaaren. $Z$ BevölkWiss. 8, 15.

HÖPFLINGER, F. \& KÜHNE, F. (1979) Die ideale Kinderzahl von Ehefrauen und Ehemannern: Sekundäranalyse einer Befragung von Schweizer Ehepaaren. Z. BevölkWiss. 5, 317.

JACo, D.E. \& ShEPARD, J.M. (1975). Demographic homogeneity and spousal consensus: a methodological perspective. J. Marriage \& Fam. 37, 161.

Jürgens, H.W. \& PoHL, K. (1978) Partnerbeziehung und generatives Verhaltan. Ergebnisse einer Longitudinaluntersuchung. Z. BevölkWiss. 4, 247.

LERIDON, H. (1980) Les facteurs de la fécondité dans les pays développés. In: Proceedings of World Fertility Survey Conference 1980, Vol. 1. World Fertility Survey, London.

Lightbourne, R. \& SINGH, S. (1982) The World Fertility Survey: charting global childbearing. Popul. Bull. 37, 1.

R YDER, N.B. (1975) Fertility measurement through cross-sectional surveys. Social Forces, $54,7$.

UDRY, J.R. (1982) The effect of normative pressures on fertility. Popul. Envir. 5, 109. 